\title{
TQM and Performance Linkage in the Microfinance Institutions: The Mediating Role of IT Capability
}

\author{
Abdo Ali Homaid ${ }^{1}$, Mohd Sobri Minai ${ }^{1} \&$ Hamzah Abdul Rahman ${ }^{1}$ \\ ${ }^{1}$ College of Business, Universiti Utara Malaysia, Kedah, Malaysia \\ Correspondence: Abdo Ali Homaid, College of Business, Universiti Utara Malaysia. Tel: 60-12-401-4925. \\ E-mail: a3hd2000@yahoo.com
}

Received: April 19, 2015 Accepted: May 11, 2015 Online Published: June 25, 2015

doi:10.5539/ass.v11n21p URL: http://dx.doi.org/10.5539/ass.v11n21p213

\begin{abstract}
The link between Total Quality Management (TQM) and organizational performance measures has become of great interest to both researchers and practitioners alike during the last decade. However, a thorough literature review has revealed such relationship is not being studied in the microfinance institutions and, furthermore, on the effect on Information Technology (IT) capability of such relationship. This paper is written based on a study done to examine the nature of such relationship that revealed the mediating effect of IT capability in the relationship between TQM and the performance of microfinance banks in Yemen. The study was conducted in 2014 using a questionnaire survey covering 78 branch managers. Using Smart Partial Least Squares (PLS), the results provide a significant relationship between TQM and microfinance institutional performance and also a significant mediating effect of IT capability on the relationship. The elements representing the variables under study are presented and some practical suggestions and contributions are highlighted in the conclusion.
\end{abstract}

Keywords: TQM, IT Capability, Microfinance Performance, Yemen

\section{Introduction}

The liberalization and explosive commercialization of microfinance sector have led to a new challenging environment. Dacheva (2009) claims the fierce competition, profitability and regulations emerge as the result of such liberalization and explosive commercialization of the sector. This tendency towards commercialization of microfinance has changed the strategy of Microfinance Institutions (MFIs) to provide their services on a commercial basis rather than giving much focus on social mission (Cull, Demirguc-Kunt, \& Morduch, 2009). We argue that microfinance commercialization is indispensable because MFIs can obtain necessary funding from the market and expand their financial services to the poor, and this issue has been highlighted by Zerai and Rani (2012).

In Yemen, there is a remarkable increase in microfinance commercialization markets and its related activities. Abdel Baki, Zain and Cordier (2010) suggested that this trend has made the MFIs become more competitive and gain a better position in the Yemeni financial industry. There are a number of researches in this sub-sector, however, only a few are found to discuss about the MFIs performance and the factors contributing to it. Considering this situation, this study has been conducted to establish the relationship between the Total Quality Management (TQM) and the MFIs performance, and examine the effect of Information Technology (IT) capability on such relationship.

TQM strategy has been cited as among the most important factors for survival and growth of organizations as well as for gaining competitive advantage (Nair, 2006; El Shenawy, Baker, \& Lemak, 2007; Irfan \& Kee, 2013). However, studies related to TQM and its relationship on the organizational performance in the service industry are limited. In the microfinance sub-sector, it is even scarcer. If there is any, particularly in Yemen, the context is envisaged by improving the loan collection performance. Khaled (2011) argued about the implementation of TQM but, still, the focus does not cover the performance of the MFIs in general. The findings related to TQM and organizational performance relationship turn out to be inconsistent (Nair, 2006) and this calls for an extensive research work to be conducted in this field. MFIs are different from business organizations or even financial institutions like banks and non-bank financial companies as they have social objectives apart from making a profit (Roy \& Goswami, 2013). Thus, it is evident that there is a need to investigate on this relationship in the microfinance industry. 
According to Prajogo and Hong (2008), the TQM practices have been confirmed to be effective not only for quality implementation and enhancement but to build a wide range of organizational capabilities. Yusr, Mokhtar, and Othman (2014) revealed that TQM principles affect positively and significantly technological innovation capabilities in the manufacturing sector, whilst Akgün, Ince, Imamoglu, Keskin, and Kocoglu (2014) reported the significant effect of TQM practices on learning capability as one of the organizational capabilities. Still, studies dedicated to test the effect of TQM on organizational capabilities are limited (Yusr, Othman, \& Mokhtar, 2012).

The role of IT is undeniably important and its capability is considered as a key element in an organization to foster performance (Liu Zhao, Wang, \& Xiao, 2013). Furthermore, it has been identified to provide a basis of obtaining a competitive advantage (Bhatt $\&$ Grover, 2005) when IT gained its ground in the early $21^{\text {th }}$ century. Despite the fact that many studies reported the significant effect of IT capability on organizational performance (for examples, Yu \& Xin-quan, 2011; Ong \& Chen, 2013; Karimi Mazidi, Amini, \& Latifi, 2014), this relationship, however, is not confirmed directly (Lee, Kim, Paulson \& Park, 2008; Pérez-López \& Alegre, 2012). Within the context of microfinance performance, studies on the impact of IT capability is even limited.

It is suggested that IT capability can acquire, integrate and deploy resources in a specific way that better fit the market environment opportunities and consequently a competitive advantage is obtained (Eisenhardt \& Martin, 2000; Morgan, Slotegraaf, \& Vorhies, 2009). It is also stated that the relationship between organizational capabilities, resources and performance is complex and capabilities can be used as mediators in the relationship between organizational resources and performance ( $\mathrm{Lu}$, Zhou, Bruton, \& $\mathrm{Li}, 2010)$. It is also stated that organizational capabilities are the most likely to be mediators in the relationship between resources and performance in the current literature (Liang, You, \& Liu, 2010).

The above discussions raise the issue of how IT capability contributes to the organizational performance as indicated by the TQM, in particular for the MFIs. This paper discusses the findings regarding the mediating role of IT capability from a study examining the relationship between TQM and the performance of banks practicing microfinance in Yemen.

\section{Literature Review}

The theory of Resource-Based View (RBV) of the firm has gained prominent attention to be the major theory in strategic management (Galbreath, 2005; Liang et al., 2010; Almarri \& Gardiner, 2014). The basic argument of RBV is that firm performance is substantially determined by the key and unique resources it owns. When the firm possesses more valuable, but scarce resources, it is more likely to create a sustainable competitive advantage and achieve better performance (Barney, 1991; Fahy, 2000). It is also argued that organizations with a combination of these resources can improve special capabilities which in turn obtain a sustainable competitive advantage and achieve higher performance (Barney, 1991; Barney \& Clark, 2007). However, this theory has been criticized for its inability to explain how organizational resources are integrated, developed and deployed to gain sustainable competitive advantage (Priem \& Butler, 2001; Morgan, Vorhies, \& Mason, 2009; Kraaijenbrink, Spender, \& Groen, 2010; El Shafeey \& Trott, 2014). Therefore, the resource deployment approach has been introduced in order to overcome such shortcomings (Shin \& Aiken, 2012) and there has been an attempt to conceptually connect resources to capabilities, which is expected to improve the other resources in the organization (Ahn \& York, 2011; Makadok, 2001). In this view, TQM practices are considered as valuable organizational resources that can enhance organizational capabilities and eventually result in higher performance.

Crook, Ketchen, Combs, and Todd (2008), who carried out a study in strategic management, argued that RBV "has emerged as a key perspective guiding inquiry into the determinants of organizational performance". However, the dynamic capability in the form of IT capability is introduced to address the theoretical shortcomings of RBV on the issues of having continual success and sustained competitive advantage in swift changing environments (Eisenhardt \& Martin, 2000; Teece, Pisano, \& Shuen, 1997; Pavlous, 2004). The complementarity is also used to address the limitation of RBV on the issues of isolation of resources in generating or sustaining competitive advantage rather than on the complementarity of resources (Mueller, 1996; Powell, 1995; Melville, Kraemer, \& Gurbaxani, 2004). In a nutshell, this study adopts RBV, dynamic capability and complementarity theories as underpinning theories.

\subsection{Organizational Performance}

Organizational performance is regarded as one of the major constructs in the area of strategic management (Combs, Crook, \& Shook, 2005; Kirby, 2005; Richard, Devinney, Yip, \& Johnson, 2009). This is because of the practical importance of the organizational performance concept, which has been always given much concern by 
top managers being related to the long term success and competitiveness of their organizations (Jusoh, Ibrahim, \& Zainuddin, 2008; Finkelstein \& Hambrick, 1996). Therefore, both academicians and practitioners carried out extensive research work on organizational performance exploring the antecedents, processes, and other variables that can improve the organizational outcomes (Jing \& Avery, 2008). Specifically, much focus was given to the organizational performance construct, driven by the desire to identify the determinants of superior performance (Al-Dhaafri, Yusoff, \& Al-Swidi, 2013).

Shareholder theory and stakeholder theory are the most important and key ways to be used as the bases for different measurement frameworks and models (Owen, 2006; Brown \& Fraser, 2006). In this regard, the organization is seen as belonging to shareholders and the shareholder return is used to measure the overall organizational performance (Hubbard, 2006). This indicates why it is a predominant organizational performance measurement system (Richard et al., 2009) beside several other financial measures to measure the organizational performance such as return on assets (ROA), Return on Investment (ROI) Return on Equity (ROE), and Earnings per Share (EPS).

On the other hand, the organization is seen as belonging to stakeholders rather than simply a shareholder (Brown \& Fraser, 2006; Steurer, 2006). Based on this view, many organizations have adopted multidimensional and balanced models including non-financial measures such as Service Profit Chain (Heskett, Jones, Sasser, \& EarlSchlesinger, 1994), Performance Prism (Neely, Adams, \& Kennerley, 2002), Multi-Model Performance Framework (Weerakoon, 1996), and the most popular measurement model in measuring organizational performance, the balanced scorecard (Kaplan \& Norton, 2008). This view considers both financial and non-financial indicators because the organizations are getting changed over time (Chenhall, 2005). Moreover, financial measures are not directly concerned with the organization's strategy and may conflict with strategic objectives (Tangen, 2004).

\subsection{Microfinance Institutions Performance}

The microfinance institution performance, the prime issue under investigation in this study is regarded as a crucial issue as it determines the efficiency of fund utilization, injected by donors in these institutions and assists regulators in controlling and monitoring the institution (Mustafa \& Saat, 2013). The MFIs are recognized to be established with the aim of poverty alleviation (Zerai \& Rani, 2012) so donors and governments have to make sure that these institutions are performing well (Mustafa \& Saat, 2013). Whilst the ample literature on organization and organizational performance is available, there is limited literature on MFIs performance and even there is no consensus regarding the definition of microfinance performance. Roy and Goswami (2013), and Nanayakkara and Iselin (2012) mentioned that there are no instruments being developed to measure such performance because of the uniqueness and the nature of MFIs being the business with social objectives. Moreover, these MFIs are providing financial services to low income people and in many cases the funds are used for personal purposes, which make measuring the MFIs performance not easy.

Within the context of MFIs, the performance measure is influenced by two major schools of thought, which are the welfarist school and institutionalist school (Berguiga, 2009; Bassem, 2012). Studies related to welfarist school focus on the effect of microfinance on the poor people, imply that the effect on the poverty level of the borrowers as the performance of the MFIs. The measures used to reveal the impact of the MFIs on the poor people are the household income, expenditure on healthcare, clothing, water supply and building a quality of a dwelling house (Ghalib, Malki, \& Imai, 2011). For the studies related to institutionalist school, the focus is mainly on the efficiency of MFIs to generate profit and to reach more the poor people. Measures such as profitability (Kamukama, 2010; Kamukama, 2011), sustainability (Thapa, 2009; Kinde, 2012) and efficiency (Caudill, Gropper, \& Hartarska, 2009; Haq, Skully, \& Pathan, 2010) used as single dimensions to measure the performance based on the view of institutional school.

For the MFIs performance measurement, there are many attempts to develop strategic performance measurement systems that consider the multidimensional aspect of measuring the overall performance of MFIs. For example, Nanayakkara and Iselin (2012) proposed that four dimensions, namely sustainability, the breadth of the outreach, depth of outreach, and portfolio at risk. Another performance measurement framework introduced by Mustafa and Saat (2013) suggests for the use of outreach and self-sustainability (one aspect) and the social impact of the change in the client's income as a direct microfinance outcome. For Roy and Goswami (2013) who propose a conceptual framework known as $360^{\circ}$ approach to assess the overall performance of the MFIs, the dimensions cover the financial performance, outreach, sustainability, efficiency, social performance, institutional characteristics, productivity, and governance. 
It is suitable to use balance scorecard, the most popular performance measurement model? The fact that many scholars use a balance scorecard to assess performance, for example Koveos and Randhawa (2004), Waweru (2010), Waweru and Spraakman (2012), and Kipesha (2013) show that such measurement can be used to measure MFIs performance with a variety of assessment measures rather than traditional financial system. This model is being adopted in the study identifying the aspects of (i) financing, (ii) customers, (iii) internal process, (iv) learning and growth, and (v) social perspective for measuring the MFIs performance. With the concern of profit and social objectives, the business and social perspectives of the MFIs are covered.

\subsection{Total Quality Management}

According to Ghadiri et al. (2013), and Demirbag, Tatoglu, Tekinkus, and Zaim (2006), quality is one of the crucial requirements for success and survival in the global market and for providing competitive advantage. It increases demand for product and services and thus contributes to the sustainability of the business. Organizations that realize the importance of quality are compelled to undergo transformations in their business models in order to provide quality products and services for customers (Lam, Lee, Ooi, \& Lin, 2011). This also leads the organizations to compete successfully in the marketplace (Ghadiri et al., 2013). Not only this, quality is also an important aspect to gain sustainable competitive advantage globally (Lin \& Su, 2013). Quality can be seen as the degree to which products and/or services delivered comprise value-added and excellent value that reach customer satisfaction.

The TQM is classified under the five broad perspectives and is viewed as management philosophy and guiding principles (Demirbag et al., 2006), as a management process (Kumar, Choisne, Grosbois, \& Kumar, 2009), as a culture (Kanji \& Wallace, 2000), as a strategy (Al-Swidi \& Mahmood, 2012) and as a system (Boon, Arumugam, $\&$ Hwa, 2005). Despite the numerous interpretations and definitions provided by different scholars, the essence of these definitions shares many common elements (Talib \& Rahman, 2011). Based on these insights, the TQM within this paper write-up is defined as a strategy, a process and an integrated system, including principles, methods and best practices aiming at achieving the MFIs overall performance. The aim is to look into the leadership and top management commitment to adopt the critical success factors of TQM, namely leadership, customer focus, strategic planning, training, continuous improvement, benchmarking, and quality culture. It enables the corporate TQM culture to be established by creating a suitable environment workplace to satisfy the internal and external customers' requirements alike.

Recent research interests regarding TQM focus on the TQM strategy and practices, measuring the performance of the organization in different sectors of the economy. For example, studies have been carried out in a diverse of economy sectors such as manufacturing (Ul Hassan, Mukhtar, Qureshi, \& Sharif, 2012; Rahman \& Bullock, 2005), multiple service sectors (Talib, Rahman, \& Qureshi, 2013; Lam et al., 2011), telecommunication sector (Iqbal, Nadeem Talib, \& Khan, 2012), health care industry (Dilber, Bayyurt, Zaim, \& Tarim, 2005; Awuor \& Kinuthia, 2013), banking sector (Al-swidi \& Mahmoud, 2012; Jaafreh \& Al-abedallat, 2012), public sector (Al Dhaafri, Yusoff, \& Al Swidi, 2014) and education (Sayeda, Rajendran, \& Lokachari, 2010). The increase in attention and interest in TQM strategy is not surprising as it is considered to be a source of competitive advantage for the organizations (Irfan \& Kee, 2013). Moreover, Nair (2006), and Chong and Rundus (2004) suggest that the TQM implementation is an effective management system, triggering a fundamental change in an organization through which the organization overcomes new market environment challenges achieving competitive survival. This indicates the right direction of TQM to the MFIs performance. From the literature, in successful TQM implementation, several principles of TQM are included such as management and leadership, customer focus, strategic planning, training, continuous improvement, benchmarking and quality culture.

\subsection{IT Capability}

According to Hemmatfar, Salehi, and Bayat (2010), and Ghobakhloo, Hong, Sabouri, and Zulkifli (2012), IT is a pivotal factor to be utilized by a firm in its operations and strategies. It is regarded as the major strategic asset in most industries (Lin, 2007) because it provides organizations with internal and external information that enable them to recognize customers, their preferences and assist in making decision to satisfy customers and then gaining sustainable competitive advantages (Lai, Zhao, \& Wang, 2006). Scholars such as Breznik (2012), and Liu et al. (2013) have highlighted that IT capability is an essential factor for organizations to compete in the market and achieve better performance.

Examining the effect of IT capability, a set of IT resources comprising IT knowledge, IT objects and an effective IT operations (which can be employed by an organization to work with other organizational resources and strategies to obtain sustained competitive advantage and gain superior performance) (Tippins \& Sohi, 2003), is being positioned as the mediating factor to the relationship as the TQM is expected to contribute better to 
organizational performance with the availability of IT capabilities (Brah \& Lim, 2006; Sánchez-Rodríguez \& Martínez-Lorente, 2011; Khanam et al., 2013).

Within the context of this paper, the IT capability is considered as the essential construct in combining with other organizational resources. It includes the capability to create a positive synergistic impact on firm performance that make a substitution, duplication or imitation is not an easy option (Liang et al., 2010; Alvarez-Suescun, 2007). As suggested by Jean, Sinkovics, and Kim (2008) that the relationship between IT and performance to be further investigated as it is still not very clear how different IT capability interacts with other organizational resources, the study construct is considered to explain the business capabilities and business processes in order to achieve better performance and to create competitive advantage.

\section{Methodology}

The main relationship under the review of the study is the relationship between TQM and MFIs performance. There are a lot of studies examining and proving the significant role of TQM implementation and practices on organizational performance (for example, the studies by Lam et al., 2011; Iqbal et al., 2012; Ul Hassan 2012; Wang, Chen, \& Chen, 2012). Whilst Munizu (2013), and Wang et al. (2012) reveal significant role of TQM, Arawati, (2005), Demirbag et al. (2006), and Su, Zhang, Liu, and Dang (2008) have reported the failure of the direct and indirect effect of TQM strategy to achieve the desired outcomes. Thus, many researches and this research have been carried out to reinvestigate such relationship in different contexts and using different contextual variables in order to generalize the results.

Thus, the principle hypothesis to test in the study is for the significant relationship between TQM and MFIs performance. In the formal form, it is stated as the following.

\section{$H_{A}$ : TQM has a positive significant impact on the performance of the MFIs.}

The next task is to examine the mediating effect of IT capability on the relationship between TQM and the MFIs. The test is for determining the mediating effect of IT capability as the partial or full mediating effect. The TQM principle implementation in the organizations generates many capabilities within the organization, which then creates the competitive advantage and thus, better performance can be achieved (Yusr et al, 2012). Empirically, TQM has been found to affect significantly organizational capabilities such as technological innovation capability, marketing capability and learning capability (Yusr et al., 2014; Yusr et al., 2012; Akgün et al., 2014).

In completing the test, the role of IT capability on the MFIs performance is investigated. Similarly, there is a bulk of researches available from the literature proving that IT capability has a direct impact on organizational performance. Interestingly, some report on the direct significant effect (Bharadwaj, 2000; Lin, 2007; Bi \& Zhang, 2008; Yu \& Xin-quan, 2011; Ong \& Chen, 2013) and other ones questioned this relationship arguing that IT capability can only influence firm performance indirectly through some mediating variables (Tippins \& Sohi, 2003; Zhu \& Nakata, 2007; Pérez-López \& Alegre, 2012). The confusing report indicates the need to examine the effect of IT capability in the model as the mediating factor. In the formal form, the hypotheses are stated as the following.

\section{$H_{A 1}$ : TQM has a positive significant impact on the IT capability. \\ $\mathrm{H}_{\mathrm{A} 2}$ : IT capability has a positive significant impact on the performance of the MFIs.}

In fact, IT capability is considered as an essential ability of the organization by which information can be managed and organizational resources such as innovation and business strategies are incorporated for superior performance (Pebrianto, 2013). Brah and Lim (2006) pointed out that IT capability serves as an enabler to quality performance as it helps to improve customer relationship management, by improving business operations effectiveness, increasing and providing high quality of services/products, giving greater flexibilities to customers and providing assistance to increase the employees' productivity. It is expected that application of IT capability improves the operational tasks of quality management and hence increase quality outcomes (Khanam, Siddiqui, \& Talib, 2013). This is the proposed possible full mediating factor of the IT capability. Therefore, this study proposes the following hypothesis.

\section{$H_{A 3}$ : IT capability mediates the relationship between TQM and the performance of the MFIs and} positively significantly.

The data collection activity was done in 2014 from the branch managers of four Yemeni banks operating in microfinance namely, Al-Amal Microfinance Bank, Alkuraimi Islamic Microfinance Bank, Tadhamon Microfinance Islamic Bank, and Cooperative and Agricultural Credit (CAC) Bank. They are the reliable source due to their executive position and their ability to provide information on the implementation of strategies in the 
organizations (Al-Swidi \& Mahmood, 2011; Al-Swidi \& Al-Hosam, 2012). Out of 108 distributed questionnaires, only 78 usable questionnaires were returned and used as the data for the analysis.

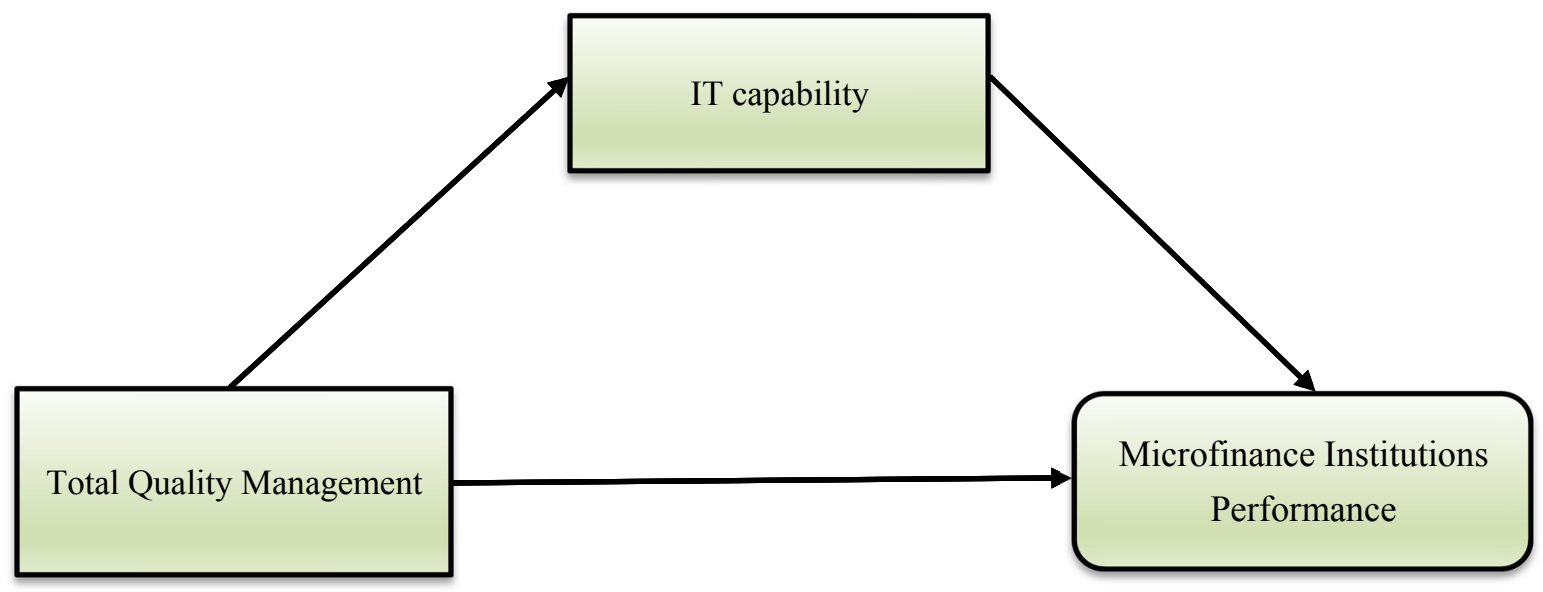

Figure 1. Theoretical framework

In measuring the performance of MFIs as a single construct, five dimensions, proposed by Kaplan and Norton (1993), as highlighted by Kipesha (2013), Nanayakkara and Iselin (2012), and Roy and Goswami (2013) are covered, namely, the financial, internal business, customer, and innovation and learning, and social dimension.

Although the measurements have been the subject of much debate among TQM scholars (Samson \& Terziovski, 1999), particular TQM success factors have been noticeably investigated in TQM literature. For the TQM success factors measure, the study derives the measures from the works of Lam et al. (2011), Wang et al. (2012), Conca (2004), Brah, Wong, and Rao (2000), and Talib et al. (2013). These measures have been validated in the context of service industries.

The IT capability measurement developed by Tippins and Sohi (2003) is used to examine its mediating effect. It includes three dimensions, which are the IT knowledge, IT objects and IT operations as validated by Li, Chen and Huang (2006). Most recent studies such as Pérez-López and Alegre (2012), and Ringim, Razalli, and Hasnan (2012) have used this measurement. According to Liu et al. (2013), this kind of measurement has been found to be a more significant effect on organizational performance compared to other measurements that can be classified from integrated aspects.

\section{Findings}

The findings presented are the result from the analysis using Smart Partial Least Squares (PLS) version 3.0. It follows the two-step approach of the outer model assessment and the assessment of the inner model as suggested by (Hair, Ringle, \& Sarstedt, 2011; Valerie, 2012; Henseler, Ringle \& Sinkovics, 2009; Hair, Hult, Ringle, \& Sarstedt, 2014). In the first step, the measurement model (outer model) was assessed to ensure the construct validity and reliability through content validity, convergent validity and discriminant validity. In the second step, the quality of the structural model was assessed by the R-square value, effect size, and predictive relevance of the model. Eventually, the hypothesized relationships were tested by running PLS bootstrapping in PLS 3.0.

\subsection{The Measurement and Structural Model}

For the structural equation modeling, the construct, convergent, and discriminant validity were examined to assess the goodness of measure (Hair et al., 2011; Valerie, 2012). The construct content validity measures, which include factor loadings, are loaded at 0.70 or higher. The convergent validity, which includes Composite Reliability (CR), Cronbach's alpha and Average Variance Extracted (AVE), the values of both CR, Cronbach's alpha is set higher than 0.70 and the values of the AVE to exceed the generally recognized 0.50 threshold as illustrated in Table 1 below. 
Table 1 . The content and convergent validity analysis

\begin{tabular}{|c|c|c|c|c|c|}
\hline Construct & Items & Loadings & Cronbach's Alpha & $\mathrm{CRa}$ & $\mathrm{AVEb}$ \\
\hline \multirow{3}{*}{ Benchmarking } & BM1 & 0.896 & \multirow{3}{*}{0.876} & \multirow{3}{*}{0.923} & \multirow{3}{*}{0.801} \\
\hline & BM2 & 0.915 & & & \\
\hline & BM3 & 0.873 & & & \\
\hline \multirow{2}{*}{ Customer Focus } & $\mathrm{CF} 1$ & 0.906 & \multirow{2}{*}{0.773} & \multirow{2}{*}{0.898} & \multirow{2}{*}{0.815} \\
\hline & CF3 & 0.899 & & & \\
\hline \multirow{2}{*}{ Continuous Improvement } & CI1 & 0.868 & \multirow{2}{*}{0.717} & \multirow{2}{*}{0.876} & \multirow{2}{*}{0.779} \\
\hline & $\mathrm{CI} 2$ & 0.897 & & & \\
\hline \multirow{2}{*}{ Customer Perspective } & $\mathrm{CP} 1$ & 0.897 & \multirow{2}{*}{0.715} & \multirow{2}{*}{0.875} & \multirow{2}{*}{0.778} \\
\hline & $\mathrm{CP} 2$ & 0.867 & & & \\
\hline \multirow{2}{*}{ Financial Perspective } & FP1 & 0.857 & \multirow{2}{*}{0.727} & \multirow{2}{*}{0.879} & \multirow{2}{*}{0.784} \\
\hline & FP2 & 0.912 & & & \\
\hline \multirow{3}{*}{ IT Objects } & ITB1 & 0.855 & \multirow{3}{*}{0.798} & \multirow{3}{*}{0.882} & \multirow{4}{*}{0.713} \\
\hline & ITB2 & 0.889 & & & \\
\hline & ITB3 & 0.787 & & & \\
\hline & ITK1 & 0.879 & & & \\
\hline IT Knowledge & ITK2 & 0.840 & 0.844 & 0.906 & 0.762 \\
\hline & ITK3 & 0.899 & & & \\
\hline & ITP1 & 0.816 & & & \\
\hline IT Operation & ITP3 & 0.757 & 0.706 & 0.836 & 0.630 \\
\hline & ITP4 & 0.806 & & & \\
\hline I onrning and Grouth Dorenetive & LGP1 & 0.907 & 0723 & 0881 & 0780 \\
\hline Learnmg and Grow me Perspective & LGP2 & 0.868 & 0.135 & 0.881 & 0.188 \\
\hline & LM1 & 0.819 & & & \\
\hline Ioodorchinond Manoromont & LM2 & 0.706 & 0.925 & 0884 & 0657 \\
\hline Leadersnip and ivanagement & LM4 & 0.841 & 0.825 & 0.884 & 0.051 \\
\hline & LM5 & 0.866 & & & \\
\hline Internal nrocess Persnective & PP1 & 0.916 & 0731 & 0880 & 0786 \\
\hline miernal process Perspective & PP2 & 0.856 & 0.131 & 0.880 & 0.180 \\
\hline & QC1 & 0.709 & & & \\
\hline & QC2 & 0.771 & & & \\
\hline Quality Culture & QC3 & 0.700 & 0.772 & 0.845 & 0.521 \\
\hline & QC4 & 0.718 & & & \\
\hline & QC7 & 0.711 & & & \\
\hline Social nersnective & SOP1 & 0.923 & 0823 & 0019 & 0840 \\
\hline social perspective & SOP2 & 0.920 & 0.823 & 0.919 & 0.849 \\
\hline & SP1 & 0.828 & & & \\
\hline Strateris Planning & SP2 & 0.791 & 0820 & 0881 & 0640 \\
\hline Strategic Pranning & SP3 & 0.818 & 0.820 & 0.881 & 0.049 \\
\hline & SP4 & 0.785 & & & \\
\hline & TR1 & 0.741 & & & \\
\hline & TR2 & 0.760 & & & \\
\hline Training & TR3 & 0.722 & 0.831 & 0.881 & 0.598 \\
\hline & TR4 & 0.784 & & & \\
\hline & TR5 & 0.853 & & & \\
\hline
\end{tabular}

The insights also show that the discriminant validity of the outer model is verified and confirmed as none of the interrelations of the instruments are greater than the square root of the AVE of the instrument as shown in Table 2 below. For the structural model, the inner model is analyzed where four criteria are examined, namely the $\mathrm{R}^{2}$ values, effect size $\left(\mathrm{f}^{2}\right)$, predictive relevance of the model, and the level and significance of the path coefficients (Chin, 2010; Hair et al., 2011; Valerie, 2012). The $\mathrm{R}^{2}$ score shows the variance in the endogenous latent variables shows the value for IT capability was 0.317 . This indicates that $31.7 \%$ of the variance in IT capability is explained by TQM. The $\mathrm{R}^{2}$ value of the MFIs performance was 0.298 indicating that $29.8 \%$ of the variance in the MFIs performance is explained by both TQM and IT capability. This is considered substantial under criterion $\mathrm{R}^{2}$ evaluation recommended by Cohen (1988). 
Table 2. Discriminant validity matrix

\begin{tabular}{|c|c|c|c|c|c|c|c|c|c|c|c|c|c|c|c|}
\hline & $\mathrm{BM}$ & $\mathrm{CF}$ & $\mathrm{CI}$ & $\mathrm{CP}$ & FP & ITB & ITK & ITP & LGP & LM & $\mathrm{PP}$ & $\mathrm{QC}$ & SOP & SP & TR \\
\hline $\mathrm{BM}$ & 0.895 & & & & & & & & & & & & & & \\
\hline $\mathrm{CF}$ & 0.244 & 0.903 & & & & & & & & & & & & & \\
\hline CI & 0.333 & 0.58 & 0.883 & & & & & & & & & & & & \\
\hline $\mathrm{CP}$ & 0.069 & 0.271 & 0.098 & 0.882 & & & & & & & & & & & \\
\hline FP & 0.338 & 0.155 & 0.083 & 0.422 & 0.885 & & & & & & & & & & \\
\hline ITB & 0.295 & 0.399 & 0.411 & 0.251 & 0.336 & 0.845 & & & & & & & & & \\
\hline ITK & 0.076 & 0.272 & 0.102 & 0.037 & 0.17 & 0.534 & 0.873 & & & & & & & & \\
\hline ITP & 0.272 & 0.221 & 0.277 & 0.253 & 0.36 & 0.699 & 0.334 & 0.793 & & & & & & & \\
\hline LGP & 0.206 & 0.377 & 0.452 & 0.228 & 0.281 & 0.455 & 0.336 & 0.363 & 0.888 & & & & & & \\
\hline $\mathrm{LM}$ & 0.343 & 0.625 & 0.588 & 0.264 & 0.169 & 0.516 & 0.335 & 0.291 & 0.413 & 0.81 & & & & & \\
\hline PP & 0.048 & -0.037 & 0.062 & 0.114 & 0.308 & 0.112 & 0.147 & 0.233 & 0.442 & -0.073 & 0.886 & & & & \\
\hline QC & 0.116 & 0.553 & 0.333 & 0.455 & 0.257 & 0.408 & 0.223 & 0.142 & 0.349 & 0.385 & 0.074 & 0.722 & & & \\
\hline SOP & 0.184 & -0.017 & 0.224 & 0.172 & 0.22 & 0.253 & -0.024 & 0.296 & 0.194 & 0.173 & 0.099 & 0.157 & 0.922 & & \\
\hline $\mathrm{SP}$ & 0.466 & 0.604 & 0.715 & 0.311 & 0.246 & 0.533 & 0.171 & 0.466 & 0.443 & 0.765 & 0.024 & 0.364 & 0.226 & 0.806 & \\
\hline TR & 0.609 & 0.488 & 0.505 & 0.165 & 0.415 & 0.589 & 0.322 & 0.511 & 0.443 & 0.493 & 0.201 & 0.317 & 0.266 & 0.625 & 0.773 \\
\hline
\end{tabular}

Table 3. The effect Size of the latent variables

\begin{tabular}{ccccccc}
\hline Construct & $\begin{array}{c}\mathrm{R}^{2} \\
\text { included }\end{array}$ & $\begin{array}{c}\mathrm{R}^{2} \\
\text { excluded }\end{array}$ & $\mathrm{R}^{2}$ included- $\mathrm{R}^{2}$ excluded & 1- $^{2}$ included & $\begin{array}{c}\text { Effect } \\
\text { Size }\left(\mathrm{f}^{2}\right)\end{array}$ & Effect Size Rating \\
\hline TQM & 0.298 & 0.221 & 0.077 & 0.702 & 0.109 & Small effect \\
IT capability & 0.298 & 0.239 & 0.059 & 0.702 & 0.084 & Small effect \\
\hline
\end{tabular}

The effect size $\left(\mathrm{f}^{2}\right)$ analysis is presented to complement the $\mathrm{R}^{2}$ value employed to determine the effect sizes of specific latent variables' impact upon the dependent variables (Chin, 2010). Cohen (1988) suggests the $\mathrm{f}^{2}$ values of 0.02 represents small, 0.15 represents medium and 0.35 represents large effect sizes of the predictive variables. The results illustrated in Table (3) above showed that a small effect size of TQM on MFIs performance with $\mathrm{f}^{2}$ values of 0.109 and similarly a small effect size of IT capability has been found on MFIs performance with $\mathrm{f}^{2}$ values of 0.084 .

In regard to the predictive relevance of the model, the Smart PLS 3.0 results highlighted in Table (4) below indicate that the cross-validated redundancy of IT capability was 0.132 and MFIs performance was 0.153 . As it is more than zero, it can be confirmed that the model has an adequate prediction quality (Fornell \& Cha, 1994).

Table 4. Predictive Quality Indicators of the Model

\begin{tabular}{ccccc}
\hline Variable & Variable Type & R square & Cross-Validated Redundancy & Cross-Validated Commonality \\
\hline Total Quality Management & & & & 0.280 \\
IT capability & Endogenous & 0.317 & 0.132 & 0.317 \\
MFIs performance & Endogenous & 0.298 & 0.081 & 0.153 \\
\hline
\end{tabular}

Unlike the other Structural Equation Modeling, PLS has only one measure of Goodness of Fit (GoF) which is called the global GoF measure (Tenenhaus, Esposito, Chatelin, \& Lauro, 2005), which involves the calculation of geometric mean of the AVE and the average $\mathrm{R}^{2}$ for the endogenous variables. According to Wetzels, Odekerken-Schröder, and Oppen (2009), the threshold values of GoF can be 0.1, 0.25 and 0.36 which represent small, medium and large respectively. The model GoF measure of this study was large with the GoF value of 0.44 which refers to an adequate and valid global PLS model.

\subsection{Hypothesis Testing}

Upon the goodness of the measurement model being established, the hypotheses were tested and the PLS algorithm path coefficient and bootstrapping results were generated. 
Table 5. Hypothesis testing results

\begin{tabular}{|c|c|c|c|c|c|c|}
\hline No. & Hypothesis Path & Path Coefficient & Standard Error & $\mathrm{T}$ Value & P Value & Decision \\
\hline $\mathrm{H}_{\mathrm{A}}$ & TQM -> MFIs per & 0.325 & 0.163 & $1.993 * *$ & 0.023 & Supported \\
\hline $\mathrm{H}_{\mathrm{A} 1}$ & TQM -> IT cap & 0.562 & 0.097 & $5.802 * * *$ & 0.000 & Supported \\
\hline $\mathrm{H}_{\mathrm{A} 2}$ & IT cap -> MFIs per & 0.292 & 0.184 & $1.589^{*}$ & 0.056 & Supported \\
\hline
\end{tabular}

Significant level: ***: $\mathrm{p}<0.001 ; * *: \mathrm{p}<0.05 ; *: \mathrm{p}<0.1$

The results proved that TQM has a positive and a significant effect on the performance of MFIs $(\beta=0.325, \mathrm{t}=$ $1.993, \mathrm{p}<0.05)$. The hypothesis null was rejected at the significance level of $5 \%$. This result shows the importance role of TQM for fostering MFIs performance. It also shows that TQM has a strong positive significant effect on IT capability $(\beta=0.562, \mathrm{t}=5.802, \mathrm{p}<0.001)$. For this one, the null hypothesis was rejected at the significance level of $0.1 \%$. This result indicates the significant role of organizational resources such as TQM on organizational capabilities (IT capability). Similarly, IT capability has a positive and significant effect on MFIs performance, but at the significant level slightly above $5 \%(\beta=0.292, t=1.589, p<0.056)$.

In testing the mediating effects of IT capability in the relationship between TQM and MFIs performance, the Smart PLS estimates the indirect effect among these variables. The bootstrapping method was used together with the other two methods the Baron and Kenny method and the Variance Accounted For (VAF) method. The bootstrapping results illustrated in Table 6 below shows that the IT capability has significantly an indirect effect on the performance of MFIs $(\beta=0.0 .192, t=1.547, p<0.10)$. This indicates that IT capability is verified as a mediator in the link between TQM and MFIs performance.

Table 6. The mediating effect results

\begin{tabular}{ccccccc}
\hline Path & $\begin{array}{c}\text { Path } \\
\text { Coefficient }\end{array}$ & $\begin{array}{c}\text { T. } \\
\text { Value }\end{array}$ & $\begin{array}{c}\mathrm{P} \\
\text { value }\end{array}$ & $\begin{array}{c}\text { Bootstrapping } \\
\text { Method }\end{array}$ & $\begin{array}{c}\text { Baron \& Kenny } \\
\text { Method }\end{array}$ & $\begin{array}{c}\text { Variance Accounted For } \\
\text { (VAF) }\end{array}$ \\
\hline $\mathrm{A}$ & $0.562 * * *$ & 5.802 & 0.000 & & & \\
$\mathrm{~B}$ & $0.292^{*}$ & 1.589 & 0.056 & & & Partial Mediation \\
$\mathrm{a} * \mathrm{~b}$ & $0.192^{*}$ & 1.547 & 0.061 & Mediating Effect & Partial Mediation & \\
$\mathrm{C}$ & $0.489^{* * *}$ & 5.798 & 0.000 & & & \\
$\mathrm{c}^{\prime}$ & $0.325^{*}$ & 1.993 & 0.023 & & \\
VAF & & 0.371 & & & \\
\hline
\end{tabular}

Significant level: ***: $\mathrm{p}<0.001 ;{ }^{* *}: \mathrm{p}<0.05 ;{ }^{*}: \mathrm{p}<0.1$

The Baron and Kenny method has approved and confirmed the mediating effect of IT capability in the relationship between TQM and MFIs performance as,

1. The TQM as the predictor variable significantly affecting the IT capability as mediator variable.

2. The IT capability as a mediating factor significantly affecting the MFIs performance, the dependent variable.

3. The TQM as the predictor variable is also significantly affecting the MFIs performance (dependent variable) when the IT variable (mediating variable) was excluded from the model.

The results show that the effect of TQM is positive and significant to the MFIs performance $(\beta=0.489, t=5.798$, $\mathrm{p}<0.001)$ in the case of IT capability exclusion also when the IT capability is included $(\beta=0.325, \mathrm{t}=1.993$, $\mathrm{p}<0.05$ ). However, the effect of TQM on MFIs performance is observed to be lower with the inclusion of IT capability. Further test on the effect of TQM on MFIs performance in the presence of IT capability shows that it is not significant. It indicates that IT capability is to be verified as a partial mediator instead of a full mediator.

The VAF method is also utilized to estimate the magnitude of the indirect effect of TQM on MFIs performance through IT capability. Hair et al. (2014) suggested that when the VAF is higher than 0.80, it is interpreted full mediation, while a value less than 0.20 , it is concluded no mediation and when the VAF is between 0.20 and 0.80 , it is characterized as partial mediation. In this study, the VAF value illustrated in Table 6 shows that $37.1 \%$ of the total effect of TQM on MFIs performance was explained by indirect effects of IT capability and a partial mediation was confirmed. This result also concludes that IT capability can be characterized as a partial mediator of the mentioned relationship. 


\section{Discussion}

The key finding of the study shows that TQM has a positive and significant effect on MFIs performance at the significance level of 5\%. This indicates that the performance of MFIs in Yemen, in the Middle-East countries, can be improved as a result of TQM implementation. The results are consistent with previous researches in the other non-Arab countries examining the effect of TQM on firm performance, such as by Lam et al. (2011), Wang et al. (2012), and Munizu (2013).

More importantly, the result of our study reveals more evidences regarding the mediating effects of IT capability on the relationship between TQM and MFIs performance. It is proven that TQM has a strong positive effect on IT capability (at significance level of $1 \%$ ), which indicates that implementing TQM significantly results in building and improving IT capability. IT capabilities are needed so that TQM implementation can significantly influence the MFIs performance. Although the significance level of $10 \%$ is reported in this study on the relation between IT capability and the MFIs performance, this level is accepted and a conclusion is made allocating necessary resources to build IT capabilities is important for MFIs performance improvement. The first finding is in line with the view of Yusr et al. (2012) who argue TQM strategy can be implemented to promote organizational capabilities together with the technological innovation capability that result in gaining competitive advantage and superior performance. It is also similar to the evidence provided by Yusr et al. (2014), Yusr et al. (2012), and Akgün et al. (2014) who also include the marketing capability and learning capability in their studies linking TQM to the organization. The second finding is compatible with prior studies that confirmed the significant role of IT capability on the performance of organizations, such as by Bharadwaj (2000), Lin (2007), Bi and Zhang (2008), Yu and Xin-quan (2011), and Ong and Chen (2013).

Such mediating effect of IT capability on the relationship between TQM and MFIs performance is viewed as partial mediation. In general, when explaining the relationship between TQM and organizational performance, most scholars suggest for the full mediating factor of IT capability, however, for the MFIs performance where our study is the first attempt to do so the finding indicates for the partial mediation. This study differs from studies that test IT capability as a moderator on such relationship, for example IT investment by Liu, Lu, and Hu (2008), service innovation by Wei-Chen (2010), and business process reengineering by Ringim et al. (2012). This finding (partial mediating effect of IT capability) that being explained by a strong connection to any one of the variables, indicates that the implementation of TQM goes together with the improvement of IT capability, however, claims cannot be made for the better MFIs performance as the result of IT capability implementation. This is against most models claiming the positive and significance effect of IT capability on organizational performance and the most logical explanation probably due to the nature of the microfinance itself.

\section{Conclusion}

The performance and sustainability of MFIs have been the crucial issues being emphasized in fighting poverty and reducing unemployment. Millions of dollars have been injected into the sector and the success of MFIs will certainly affect millions of poor people living worldwide, and the effective use of the huge funds injected by donors and investors. However, limited of knowledge regarding the success drivers that enhance the performance of MFIs is available and the research attempts to link TQM and the MFIs performance with the mediating effect of IT capability is so valuable. This result, which shows the partial mediating effect of IT (using Baron and Kenny method and VAF on the significant relationship between TQM and the MFIs performance, indicates that it is in line with the view of RBV theory regarding the role of organizational resources in building capabilities as confirmed by the significant and strong effect of TQM on IT capability, which also affecting the MFIs performance. This is supposed to be the theoretical contribution in terms of the first study to examine the integration between TQM and MFIs performance with IT capability as the mediator. Moreover, the study contributes to the resource-based view theory, capability theory and complementarity theory by providing a broader theoretical perspective regarding the role of organizational resources and capabilities and how they can be deployed to foster the MFIs organizational performance

Whilst most studies on organizational performance measures focus only on the four main perspectives of the balanced scorecard, namely financial, customer, internal process, and finally learning and growth perspective, the social perspective is not emphasized. The social perspective that has been included in this study to measure MFIs performance are actually concerned with the business as well as the social objectives. This, thus, provides an additional perspective of consideration while looking at the performance of the MFIs. Moreover, this particular study was conducted in Yemen, where the culture and religion are closely tied with the social aspect provide a new dimension to the understanding of the organizational performance, in particular the MFIs performance. 
For the practitioners, the insights can be used as the indication for policy formation and managerial implication to sustain the MFIs performance as they understand the role of TQM and IT capability on the performance of MFIs. In Yemen, the MFIs management can build strong organizational resources and develop IT competency to establish viable and enduring MFIs. The Yemeni government initiatives and strategies which aim at fighting poverty and improve the nation economy can be achieved once the MFIs performance is addressed. This study provides microfinance practitioners clear insight on how to ensure the sustainability of MFIs by understanding the role of TQM and IT capability on the performance of MFIs. IT capability should leverage the organizational resources and all employees should be trained to use IT system effectively so that TQM can better enhance the MFIs performance. Thus, in this respect, roadmap and guidelines to make necessary interventions for the development of MFIs.

For future research and more insights, it is proposed to look into other factors that potentially affecting the MFIs performance such as the organizational resources, strategies and capabilities. Such relations can be tested independently or together to reveal the bigger picture of the factors impacting the MFIs performance. Such research approach can also be applied to other type of organizational performance in finding any similarity or difference when the same study is conducted elswhere in the Middle East where the culture and people behavior are dominated by a common religion.

\section{Acknowledgements}

The authors would like to express sincere thanks and gratitude to Mr Mohammed Saleh Al-lai, Vice Chairman of the Board of Directors of Sanabel Network, who is also the Chairman of Board of Directors of Yemen Microfinance Network and the CEO of Al-Amal Microfinance bank for his great support and encouragement.

\section{References}

Abdel Baki, R., Zain, S., \& Cordier, C. (2010). MIX Microfinance World: 2010 Arab Microfinance Analysis \& Benchmarking Report. Retrieved from http://www.themix.org/sites/default/files/2010\%20Arab\%20Micro finance\%20Analysis\%20Benchmarking\%20Report\%20-Final_3.pdf

Ahn, M. J., \& York, A. S. (2011). Resource-based and institution-based approaches to biotechnology industry development in Malaysia. Asia Pacific Journal of Management, 28(2), 257-275. http://dx.doi.org/10.1007/s 10490-009-9147-2

Akgün, A. E., Ince, H., Imamoglu, S. Z., Keskin, H., \& Kocoglu, İ. (2014). The mediator role of learning capability and business innovativeness between total quality management and financial performance. International Journal of Production Research, 52(3), 888-901. http://dx.doi.org/10.1080/00207543.2013. 843796

Al Dhaafri, H. S., Yusoff, R. Z. B., \& Al Swidi, A. K. (2014). The Relationship between Enterprise Resource Planning, Total Quality Management, Organizational Excellence, and Organizational Performance-the Mediating Role of Total Quality Management and Organizational Excellence. Asian Social Science, 10(14), 158. http://dx.doi.org/10.5539/ass.v10n14p158

Al-Dhaafri, H. S., Bin Yusoff, R. Z., \& Al-Swidi, A. K. (2013). The Effect of Total Quality Management, Enterprise Resource Planning and the Entrepreneurial Orientation on the Organizational Performance: The Mediating Role of the Organizational Excellence-A Proposed Research Framework. International Journal of Business Administration, 4(1), 66-85. http://dx.doi.org/10.5430/ijba.v4n1p66

Almarri, K., \& Gardiner, P. (2014). Application of Resource-based View to Project Management Research: Supporters and Opponents. Procedia-Social and Behavioral Sciences, 119, 437-445. http://dx.doi.org/10. 1016/j.sbspro.2014.03.049

Al-Swidi, A. K., \& Al-Hosam, A. (2012). The Effect of Entrepreneurial Orientation on the Organizational Performance: A Study on the Islamic Banks in Yemen Using the Partial Least Squares Approach. Arabian Journal of Business and Management Review (Oman Chapter), 2(1), 73-84.

Al-Swidi, A. K., \& Mahmood, R. (2011). Yemeni banking system: Critical issues and future recommended strategies. European Journal of Social Sciences, 20(4), 637-655.

Al-Swidi, A. K., \& Mahmood, R. (2012). Total quality management, entrepreneurial orientation and organizational performance: The role of organizational culture. African Journal of Business Management, 6(13), 4717-4727. http://dx.doi.org/10.5897/AJBM11.2016

Alvarez-Suescun, E. (2007). Testing resource-based propositions about IS sourcing decisions. Industrial Management \& Data Systems, 107(6), 762-79. http://dx.doi.org/10.1108/02635570710758716 
Arawati, A. (2005). The structural linkages between TQM, product quality performance, and business performance: Preliminary empirical study in electronics companies. Singapore Management Review, 27(1), $87-105$.

Awuor, E. O., \& Kinuthia, D. M. (2013). Total Quality Management Practices in Selected Private Hospitals in Nairobi, Kenya. European Journal of Business and Management, 5(13), 33-44.

Barney, J. B. (1991). Firm resources and sustained competitive advantage. Journal of Management, 17(1), 99-120. http://dx.doi.org/10.1177/014920639101700108

Barney, J. B., \& Clark, D. N. (2007). Resource-based theory: Creating and sustaining competitive advantage. Oxford: Oxford University Press.

Bassem, B. S. (2012). Social and financial performance of microfinance institutions: Is there a trade-off? Journal of Economics and International Finance, 4(4), 92-100. http://dx.doi.org/10.5897/JEIF11.129

Berguiga, I. (2009). Social Performance vs. Financial Performance of Microfinance Institutions. Mimeo, East Paris University. Retrieved from http://www.gredeg.cnrs.fr/colloques/nfi/papers/PapierOnLine/Berguiga.pdf

Bharadwaj, A. (2000). A resource-based perspective on information technology capability and firm performance: An empirical investigation. MIS Quarterly, 24, 169-196. http://dx.doi.org/10.2307/3250983

Bhatt, G. D., \& Grover, V. (2005). Types of Information Technology Capabilities and their role in competitive Advantage: An Empirical Study. Journal of Management Information Systems, 22(2), 253-277. http://dx.doi.org/10.2307/40398752

Bi, X., \& Zhang, H. (2008). Empirical Research on Relationship between Information Technology Capability and Firm Performance: the Evidence from Listed Companies and Information Power 500 in China. Paper presented at the International Conference on Computer Science and Software Engineering. China. http://dx.doi.org/10.1109/CSSE.2008.12

Boon, O. K., Arumugam, V., \& Hwa, T. S. (2005). Does soft TQM predict employees" attributes? The TQM Magazine, 17(3), 279-289. http://dx.doi.org/10.1108/09544780510594243

Brah, S. A., \& Lim, H. Y. (2006). The effects of technology and TQM on the performance of logistics companies. International Journal of Physical Distribution \& Logistics Management, 36(3), 192-209. http://dx.doi.org/10.1108/09600030610661796

Brah, S. A., Wong, J. L., \& Rao, B. M. (2000). TQM and business performance in the service sector: a Singaporean study. International Journal of operations \& Production Management, 20(11), 1293-1312. http://dx.doi.org/10.1108/01443570010348262

Breznik, L. (2012). Can information technology be a source of competitive advantage? Economic and Business Review, 14(3), 251-269. Retrieved from http://www.researchgate.net/profile/Lidija_Breznik/publication/ 249998794_CAN_INFORMATION_TECHNOLOGY_BE_A_SOURCE_OF_COMPETITIVE_ADVANT AGE/links/0deec51e8f454abd17000000.pdf

Brown, J., \& Fraser, M. (2006). Approaches and perspectives in social and environmental accounting: an overview of the conceptual landscape. Business Strategy and the Environment, 15(2), 103-117. http://dx.doi.org/10.1002/bse.452

Caudill, S. B., Gropper, D. M., \& Hartarska, V. (2009). Which microfinance institutions are becoming more cost effective with time? Evidence from a mixture model. Journal of Money, Credit and Banking, 41(4), 651-672. http://dx.doi.org/10.1111/j.1538-4616.2009.00226.x

Chenhall, R. H. (2005). Integrative strategic performance measurement systems, strategic alignment of manufacturing, learning and strategic outcomes: an exploratory study. Accounting, Organizations and Society, 30(5), 395-422. http://dx.doi.org/10.1016/j.aos.2004.08.001

Chin, W. W. (2010). How to write up and report PLS analyses. In V. E. Vinzi, W. W. Chin, J. Henseler, \& H. Wang (Eds.), Handbook of Partial Least Squares (1st ed., pp. 655-690). Springer, Berlin. http://dx.doi.org/10.1007/978-3-540-32827-8_29

Chong, V. K., \& Rundus, M. J. (2004). Total quality management, market competition and organizational performance. The British Accounting Review, 36, 155-172. http://dx.doi.org/10.1016/j.bar.2003.10.006

Cohen, J. (1988). Statistical power analysis for the behavioral sciences. Hillsdale, NJ: Lawrence Erlbaum Associates. 
Combs, J. G., Crook, T. R., \& Shook, C. L. (2005). The dimensionality of organizational performance and its implications for strategic management research. Research methodology in strategy and management, 2, 259-286. http://dx.doi.org/10.1016/S1479-8387(05)02011-4

Conca, F. J., Llopis, J., \& Tarí, J. J. (2004). Development of a measure to assess quality management in certified firms. European Journal of Operational Research, 156(3), 683-697. http://dx.doi.org/10.1016/S03772217(03)00145-0

Crook, T. R., Ketchen, D. J., Combs, J. G., \& Todd, S. Y. (2008). Strategic resources and performance: a metaanalysis. Strategic management journal, 29(11), 1141-1154. http://dx.doi.org/10.1002/smj.703

Cull, R., Demirgu“c -Kunt, A., \& Morduch, J. (2009). Microfinance meets the market. Journal of Economic Perspectives, 23(1), 167-192. http://dx.doi.org/10.1257/jep.23.1.167

Dacheva, P. (2009). Commercialization in Microfinance-A Study of Profitability, Outreach and Success Factors within the Latin American Context. Sweet Briar College Working Paper. Retrieved from http://www.sbc.edu/sites/default/files/Honors/PDacheva.pdf

Demirbag, M., Tatoglu, E., Tekinkus, M., \& Zaim, S. (2006). An analysis of the relationship between TQM implementation and organizational performance: evidence from Turkish SMEs. Journal of Manufacturing Technology Management, 17(6), 829-847. http://dx.doi.org/10.1108/17410380610678828

Dilber, M., Bayyurt, N., Zaim, S., \& Tarim, M. (2005). Critical factors of total quality management and its effect on performance in health care industry: a Turkish experience. Problems and Perspectives in Management, 4, 220-234. Retrieved from http://businessperspectives.org/journals_free/ppm/2005/PPM_EN_2005_04_ Dilber.pdf

Eisenhardt, K. M., \& Martin, J. A. (2000). Dynamic capabilities: what are they? Strategic Management Journal, 21(10-11), 1105-1121. http://dx.doi.org/10.1002/1097-0266(200010/11)21:10/11<1105::AID-SMJ133>3.0. $\mathrm{CO} ; 2-\mathrm{E}$

El Shafeey, T., \& Trott, P. (2014). Resource-based competition: three schools of thought and thirteen criticisms. European Business Review, 26(2), 122-148. http://dx.doi.org/10.1108/EBR-07-2013-0096

El Shenawy, E., Baker, T., \& Lemak, D. J. (2007). A meta-analysis of the effect of TQM on competitive advantage. International Journal of Quality \& Reliability Management, 24(5), 442-471. http://dx.doi.org/10.1108/02656710710748349

Fahy, J. (2000). The resource-based view of the firm: Some stumbling block on the road to understanding sustainable competitive advantage. Journal of European Industrial Training, 24(23/4), 94-104. http://dx.doi.org/10.1108/03090590010321061

Finkelstein, S., \& Hambrick, D. C. (1996). Strategic Leadership: Top executives and their effects on organizations. New York: West.

Fornell, C., \& Cha, J. (1994). Partial least squares. Advanced methods of marketing research, 407, 52-78.

Galbreath, J. (2005). Which resources matter the most to firm success? An exploratory study of resource-based theory. Technovation, 25(9), 979-987. http://dx.doi.org/10.1016/j.technovation.2004.02.008

Ghadiri, A., Bahari, M. D., Bafrani, F. A., Alami, M., Farzaneh, M., \& Timachi, M. (2013). The survey of relationship between total quality management and financial performance. Strategies, 5(2). Retrieved from http://journal-archieves33.webs.com/590-598.pdf

Ghalib, A. K., Malki, I., \& Imai, K. S. (2011). The Impact of Microfinance and its Role in Easing Poverty of Rural Households: Estimations from Pakistan (No. DP2011-28). Retrieved from http://www.rieb.kobeu.ac.jp/academic/ra/dp/English/DP2011-28.pdf

Ghobakhloo, M., Hong, T. S., Sabouri, M. S., \& Zulkifli, N. (2012). Strategies for successful information technology adoption in small and medium-sized enterprises. Information, 3(1), 36-67. http://dx.doi.org/10. 3390/info3010036

Hair, J. F. Jr., Hult, G. T. M., Ringle, C., \& Sarstedt, M. (2013). A primer on partial least squares structural equation modeling (PLS-SEM). Sage Publications. Retrieved from http://www.sagepub.com/books/ Book237345

Hair, J. F., Ringle, C. M., \& Sarstedt, M. (2011). PLS-SEM: Indeed a Silver Bullet. Journal of Marketing Theory and Practice, 19(2), 139-151. http://dx.doi.org/10.2753/MTP1069-6679190202 
Haq, M., Skully, M., \& Pathan, S. (2010). Efficiency of microfinance institutions: A data envelopment analysis. Asia-Pacific Financial Markets, 17(1), 63-97. http://dx.doi.org/10.1007/s10690-009-9103-7

Hemmatfar, M., Salehi, M., \& Bayat, M. (2010). Competitive advantages and strategic information systems. International Journal of Business and Management, 5(7), 158.

Henseler, J., Ringle, C. M., \& Sinkovics, R. R. (2009). The Use of Partial Least Squares Path Modeling in International Marketing. Advances in International Marketing, 20(1), 277-320. http://dx.doi.org/10.1108/ S1474-7979(2009)0000020014

Heskett, J. L., Jones, T. O., Sasser, W. Jr., \& EarlSchlesinger, L. A. (1994). Putting the service-profit chain to work. Harvard Business Review, 72(2), 164.

Iqbal, T., Khan, B. A., Nadeem Talib, D., \& Khan, N. (2012). TQM and Organization Performance: The Mediation and Moderation Fit. Life Science Journal, 9(4).

Irfan, S. M., \& Kee, D. M. H. (2013). Critical Success Factors of TQM and its Impact on Increased Service Quality: A Case from Service Sector of Pakistan. Middle East Journal of Scientific Research, 15(1). http://dx.doi.org/10.5829/idosi.mejsr.2013.15.1.828

Jaafreh, A. B., \& Al-abedallat, A. Z. (2012). The Effect of Quality Management Practices on Organizational Performance in Jordan: An Empirical Study. International Journal of Financial Research, 4(1), 93. http://dx.doi.org/10.5430/ijfr.v4n1p93

Jean, R.-J. B., Sinkovics, R. R., \& Kim, D. (2008). Information technology and organizational performance within international business to business relationships: a review and an integrated conceptual framework. International Marketing Review, 25(5), 563-583. http://dx.doi.org/10.1108/02651330810904099

Jing, F. F., \& Avery, G. C. (2008). Missing Links in Understanding the Relationship between Leadership and Organizational Performance. International Business \& Economics Research Journal, 7(5), 67-78.

Jusoh, D., Ibrahim, N., \& Zainuddin, Y. (2008). The performance consequence of multiple performance measures Usage: Evidence from the Malaysian manufacturers. International Journal of Productivity and Performance Management, 57(2), 119-136. http://dx.doi.org/10.1108/17410400810847393

Kamukama, N., Ahiauzu, A., \& Ntayi, J. M. (2010). Intellectual capital and performance: testing interaction effects. Journal of Intellectual Capital, 11(4), 554-574. http://dx.doi.org/10.1108/14691931011085687

Kamukama, N., Ahiauzu, A., \& Ntayi, J. M. (2011). Competitive advantage: mediator of intellectual capital and performance. Journal of intellectual capital, 12(1), 152-164. http://dx.doi.org/10.1108/14691931111097953

Kanji, G. K., \& Wallace, W. (2000). Business excellence through customer satisfaction. Total Quality Management, 11(7), 979-998. http://dx.doi.org/10.1080/09544120050135515

Kaplan, R. S. \& Norton, D. P. (1993). Putting the balanced scorecard to work. Harvard Business Review, 9(10), $134-47$.

Kaplan, R. S., \& Norton, D. P. (2008). The execution premium: linking strategy to operations for competitive advantage. Harvard Business Press.

Karimi Mazidi, A. R., Amini, A., \& Latifi, M. (2014). The impact of information technology capability on firm performance; a focus on employee customer profit chain. Iranian Journal of Management Studies, 7(1), 95-120.

Khaled, M. (2011). Building a Successful Business Model for Islamic Microfinance. In Global Microcredit Summit Commissioned Workshop Paper. Retrieved from http://www.globalmicrocreditsummit2011.org/ userfiles/file/Workshop\%20Papers/M_Khaled\%20-\%20Building\%20a\%20Successful\%20Business\%20Mo del\%20for\%20Islamic\%20Microfinance.pdf

Khanam, S., Siddiqui, J., \& Talib, F. (2013). Role of Information Technology in Total Quality Management: A Literature Review. International Journal of Advanced Research in Computer Engineering and Technology, 2(8), 2433-2445.

Kinde, B. A. (2012). Financial sustainability of microfinance institutions (MFIs) in Ethiopia. European Journal of Business and Management, 4(15), 1-10.

Kipesha, E. F. (2013). Performance of Microfinance Institutions in Tanzania: Integrating Financial and Non-financial Metrics. European Journal of Business and Management, 5(4), 94-105.

Kirby, J. (2005). Toward a theory of high performance. Harvard business review, 83(7), 30. 
Koveos, P., \& Randhawa, D. (2004). Financial services for the poor: assessing microfinance institutions. Managerial Finance, 30(9), 70-95. http://dx.doi.org/10.1108/03074350410769281

Kraaijenbrink, J., Spender, J. C., \& Groen, A. J. (2010). The resource-based view: a review and assessment of its critiques. Journal of management, 36(1), 349-372. http://dx.doi.org/10.1177/0149206309350775

Kumar, V., Choisne, F., de Grosbois, D., \& Kumar, U. (2009). Impact of TQM on company's performance. International journal of quality \& reliability management, 26(1), 23-37. http://dx.doi.org/10.1108/026 56710910924152

Lam, S. Y., Lee, V. H., Ooi, K. B., \& Lin, B. (2011). The relationship between TQM, learning orientation and market performance in service organizations: An empirical analysis. Total Quality Management \& Business Excellence, 22(12), 1277-1297. http://dx.doi.org/10.1080/14783363.2011.631337

Li, E. Y., Chen, J. S., \& Huang, Y. H. (2006). A framework for investigating the impact of IT capability and organizational capability on firm performance in the late industrializing context. International Journal of Technology Management, 36(1), 209-229. http://dx.doi.org/10.1504/IJTM.2006.009969

Liang, T. P., You, J. J., \& Liu, C. C. (2010). A resource-based perspective on information technology and firm performance: a meta-analysis. Industrial Management \& Data Systems, 110(8), 1138-1158. http://dx.doi.org/10.1108/02635571011077807

Lin, B. W. (2007). Information technology capability and value creation: Evidence from the US banking industry. Technology in Society, 29(1), 93-106. http://dx.doi.org/10.1016/j.techsoc.2006.10.003

Lin, C. S., \& Su, C. T. (2013). The Taiwan national quality award and market value of the firms: An empirical study. International Journal of Production Economics, 144(1), 57-67. http://dx.doi.org/10.1016/j.ijpe.2013. 01.015

Liu, P., Zhao, R. Y., Wang, W. L., \& Xiao, J. (2013). Information technology capability and firm performance: A meta-analysis. In Service Systems and Service Management (ICSSSM), 2013 10th International Conference on (pp. 719-724). http://dx.doi.org/10.1109/icsssm.2013.6602519

Liu, Y., Lu, H., \& Hu, J. (2008). IT capability as moderator between IT investment and firm performance. Tsinghua Science \& Technology, 13(3), 329-336. http://dx.doi.org/10.1016/s1007-0214(08)70053-1

Lu, Y., Zhou, L., Bruton, G., \& Li, W. (2010). Capabilities as a mediator linking resources and the international performance of entrepreneurial firms in an emerging economy. Journal of International Business Studies, 4l(3), 419-436. http://dx.doi.org/10.1057/jibs.2009.73

Makadok, R. (2001). Toward a synthesis of the resource-base and dynamic capability view of rent creation. Strategic Management Journal, 22(5), 387-401. http://dx.doi.org/10.1002/smj.158

Melville, N., Kraemer, K., \& Gurbaxani, V. (2004). Review: Information technology and organizational performance: An integrative model of IT business value. MIS quarterly, 28(2), 283-322. http://dx.doi.org/10. $2307 / 25148636$

Morgan, N. A., Slotegraaf, R. J., \& Vorhies, D. W. (2009). Linking marketing capabilities with profit growth. International Journal of Research in Marketing, 26(4), 284-293. http://dx.doi.org/10.1016/j.ijresmar.2009. 06.005

Morgan, N. A., Vorhies, D. W., \& Mason, C. H. (2009). Market orientation, marketing capabilities, and firm performance. Strategic Management Journal, 30(8), 909-920. http://dx.doi.org/10.1002/smj.764

Mueller, F. (1996). Human Resources as Strategic Assets: An Evolutionary Resource-Based Theory. Journal of Management studies, 33(6), 757-785. http://dx.doi.org/10.1111/j.1467-6486.1996.tb00171.x

Munizu, M. (2013). The Impact of Total Quality Management Practices towards Competitive Advantage and Organizational Performance: Case of Fishery Industry in South Sulawesi Province of Indonesia. Pakistan Journal of Commerce \& Social Sciences, 7(1).

Mustafa, A. K., \& Saat, M. M. (2013). Performance Measurement Characteristics: A new set for Microfinance Institutions. Interdisciplinary Journal of Contemporary Research in Business, 4(10).

Nair, A. (2006). Meta-analysis of the relationship between quality management practices and firm performance-implications for quality management theory development. Journal of Operations Management, 24, 948-975. http://dx.doi.org/10.1016/j.jom.2005.11.005

Nanayakkara, G., \& Iselin, E. R. (2012). An Exploratory Study of the Performance of Microfinancing 
Institutions Using the Balanced Scorecard Approach. International Journal of Business and Information, $7(2)$.

Neely, A. D., Adams, C., \& Kennerley, M. (2002). The Performance Prism: The scorecard for measuring and managing business success. Financial Times Prentice Hall London. Retrieved from http://210.55.20.100/news/Events/Tertiary\%20Services\%20Conference/Tertiary\%20Conference/PDF's/200 9/General\%20Papers/NM\%20Performance\%2520Prism.pdf

Ong, C. S., \& Chen, P. (2013). Information technology capability-enabled performance, future performance, and value. Industrial Management \& Data Systems, 113(5), 669-682. http://dx.doi.org/10.1108/0263557131 1324133

Owen, D. (2006). Emerging issues in sustainability reporting. Business Strategy and the Environment, 15(4), 217-218. http://dx.doi.org/10.1002/bse.530

Pavlous, P. A. (2004). IT enabled dynamic capabilities in new product development: Building a competitive advantage in turbulent environments (Unpublished Dissertation). University of Southern California.

Pebrianto, A. (2013). The Influence of Information Technology Capability, Organizational Learning, and Knowledge Management Capability on Organizational Performance (A Study of Banking Branches Company in Southern Kalimantan Province). Information and Knowledge Management, 3(11), 112-120.

Pérez-López, S., \& Alegre, J. (2012). Information technology competency, knowledge processes and firm performance. Industrial Management \& Data Systems, 112(4), 644-662. http://dx.doi.org/10.1108/02635 571211225521

Powell, T. C. (1995). Total quality management as competitive advantage: A review and empirical study. Strategic Management Journal, 16(1), 15-37. http://dx.doi.org/10.1002/smj.4250160105

Prajogo, D. I., \& Hong, S. W. (2008). The effect of TQM on performance in R\&D environments: A perspective from SouthKorean firms. Technovation, 28(12), 855-863. http://dx.doi.org/10.1016/j.technovation.2008. 06.001

Priem, R. L., \& Butler, J. E. (2001). Is the resource-based "view" a useful perspective for strategic management research? Academy of management review, 26(1), 22-40. http://dx.doi.org/10.2307/259392

Rahman, S. U., \& Bullock, P. (2005). Soft TQM, hard TQM, and organisational performance relationships: an empirical investigation. Omega, 33(1), 73-83. http://dx.doi.org/10.1016/j.omega.2004.03.008

Richard, P. J., Devinney, T. M., Yip, G. S., \& Johnson, G. (2009). Measuring organizational performance: Towards methodological best practice. Journal of management, 35(3), 718-804. http://dx.doi.org/10.1177/ 0149206308330560

Ringim, K. J., Razalli, M. R., \& Hasnan, N. (2012). Moderating effect of Information technology (IT) capability on the relationship between business process reengineering factors and organizational performance of Bank. African Journal of Business Management, 6(16), 5551-5567. http://dx.doi.org/10.5897/AJBM11.2792

Roy, A., \& Goswami, C. (2013). A scientometric analysis of literature on performance assessment of microfinance institutions (1995-2010). International Journal of Commerce and Management, 23(2), 148-174. http://dx.doi.org/10.1108/10569211311324939

Samson, D., \& Terziovski, M. (1999). The relationship between total quality management practices and operational performance. Journal of operations management, 17(4), 393-409. http://dx.doi.org/10.1016/s 0272-6963(98)00046-1

Sánchez-Rodríguez, C., \& Martínez-Lorente, A. R. (2011). Effect of IT and quality management on performance. Industrial Management \& Data Systems, 111(6), 830-848. http://dx.doi.org/10.1108/02635571111144937

Sayeda, B., Rajendran, C., \& Lokachari, P. S. (2010). An empirical study of total quality management in engineering educational institutions of India: perspective of management. Benchmarking: An International Journal, 17(5), 728-767. http://dx.doi.org.sci-hub.org/10.1108/14635771011076461

Shin, S., \& Aiken, K. D. (2012). The mediating role of marketing capability: evidence from Korean companies. Asia Pacific Journal of Marketing and Logistics, 24(4), 658-677. http://dx.doi.org/10.1108/1355585121125 9070

Steurer, R. (2006). Mapping stakeholder theory anew: from the 'stakeholder theory of the firm'to three perspectives on business-society relations. Business Strategy and the Environment, 15(1), 55-69. 
http://dx.doi.org//10.1002/bse.467

Su, Q., Li, Z., Zhang, S. X., Liu, Y. Y., \& Dang, J. X. (2008). The impacts of quality management practices on business performance: an empirical investigation from China. International Journal of Quality \& Reliability Management, 25(8), 809-823. http://dx.doi.org.sci-hub.org/10.1108/02656710810898621

Talib, F., \& Rahman, Z. (2011). Pareto analysis of total quality management factors critical to success for service industries. Paper presented at 5th International Quality Conference, Center for Quality. Retrieved from http://www.cqm.rs/2011/cd/5iqc/pdf/088.pdf

Talib, F., Rahman, Z., \& Qureshi, M. N. (2013). An empirical investigation of relationship between total quality management practices and quality performance in Indian service companies. International Journal of Quality \& Reliability Management, 30(3), 280-318. http://dx.doi.org/10.1108/02656711311299845

Tangen, S. (2004). Performance measurement: from philosophy to practice. International Journal of Productivity and Performance Management, 53(8), 726-737. http://dx.doi.org/10.1108/17410400410569134

Teece, D. J., Pisano, G., \& Shuen, A. (1997). Dynamic capabilities and strategic management. Strategic management journal, 18(7), 509-533. http://dx.doi.org/10.1002/(sici)1097-0266(199708)18:7<50 9::aid-smj882>3.0.co;2-z

Tenenhaus, M., Esposito, V., Chatelin, Y. M., \& Lauro, C. (2005). PLS Path Modeling. Computational Statistics and Data Analysis, 28, 159- 205. http://dx.doi.org/10.1016/j.csda.2004.03.005

Thapa, G. (2007). Sustainability and governance of microfinance institutions: recent experiences and some lessons for Southeast Asia. Asian Journal of Agriculture and Development, 4(1), 17-37.

Tippins, M. J., \& Sohi, R. S. (2003). IT Competency and firm performance: Is organizational learning a missing link? Strategic Management Journal, 24, 745-761. http://dx.doi.org/10.1002/smj.337

Ul Hassan, M., Mukhtar, A., Qureshi, S. U., \& Sharif, S (2012). Impact of TQM Practices on Firm's Performance of Pakistan's Manufacturing Organizations. International Journal, 2(10).

Valerie, F. (2012). Re-discovering the PLS approach in management science. Management, 15(1), 101-123.

Wang, C. H., Chen, K. Y., \& Chen, S. C. (2012). Total quality management, market orientation and hotel performance: the moderating effects of external environmental factors. International Journal of Hospitality Management, 31(1), 119-129. 10. http://dx.doi.org/1016/j.ijhm.2011.03.013

Waweru, N. (2010). The appropriateness of performance measurement systems in the services sector: case studies from the microfinance sector in Kenya. Paper presented at the American Accounting Association, Management Accounting Section Conference, 6-9 January. http://dx.doi.org/10.2139/ssrn.1408262

Waweru, N., \& Spraakman, G. (2012). The use of performance measures: case studies from the microfinance sector in Kenya. Qualitative Research in Accounting \& Management, 9(1), 44-65. http://dx.doi.org/10.1108/ 11766091211216105

Wei-Chen, T. (2010). The moderating effect of IT capability on the service innovation and supply chain performance. In Technology Management for Global Economic Growth (PICMET), 2010 Proceedings of PICMET'10 (pp. 1-8). IEEE.

Wetzels, M., Odekerken-Schroder, G., \& Oppen, C. V. (2009). Using PLS path modeling for assessing hierarchical models: Guidelines and empirical illustration. MIS Quarterly, 33(1), 177-195. Retrieved from http://www.researchgate.net/profile/Gaby_Odekerken/publication/228754673_Using_PLS_path_modeling_ for_assessing_hierarchical_construct_models_guidelines_and_empirical_illustration/links/0912f50883c99a 26-14000000.pdf

Yu, C., \& Xin-quan, G. (2011). The empirical study on the relationship between information technology capability and innovation performance: The moderating role of learning commitment. In E-Business and E-Government (ICEE), 2011 International Conference on (pp. 1-4). IEEE. http://dx.doi.org/10.1109/IC EBEG.2011.5882049

Yusr, M. M., Mokhtar, S. S. M. \& Othman, A. R. (2014). The Effect of TQM Practices on Technological Innovation Capabilities: Applying on Malaysian Manufacturing Sector. International Journal for Quality Research, 8(2), 197-216.

Yusr, M. M., Othman, A. R., \& Mokhtar, S. S. M. (2012). Assessing the Mediating Role of Marketing Capability in the Relationship between TQM Practices and Innovation Performance Dynamic Capabilities Approach. 
International Journal of Business and Social Science, 3(23), 165-176.

Zerai, B., \& Rani, L. (2012). Is There a Tradeoff between Outreach and Sustainability of Micro finance institutions? Evidence from Indian Microfinance Institutions (MFIs). Research Journal of Finance and Accounting, 2(11), 32-41.

Zhu, Z., \& Nakata, C. (2007). Reexamining the link between customer orientation and business performance: the role of information systems. The Journal of Marketing Theory and Practice, 15(3), 187-203.

\section{Copyrights}

Copyright for this article is retained by the author(s), with first publication rights granted to the journal.

This is an open-access article distributed under the terms and conditions of the Creative Commons Attribution license (http://creativecommons.org/licenses/by/3.0/). 